\title{
The importance of radiological documentation in civil lawsuits involving dentists: case report
}

\author{
A importância da documentação radiológica em processos civis envolvendo cirurgiões-dentistas: relato de caso
}

Bárbara Taíny Barbosa NIQUINI ${ }^{1}$

Fernanda Capurucho Horta BOUCHARDET ${ }^{1}$

Flávio Ricardo MANZI ${ }^{1}$

\section{ABSTRACT}

This article aims to show the importance of thorough radiological documentation in dental care in lawsuits in which there is deemed a need for forensic evidence in civil liability cases involving a dentist and a patient. This study seeks to demonstrate the relationship between the drafting of the recommended documentation and the proper development of the treatment. The implications of one's non-compliance with ethical and legal duties are illustrated here through a case report of a settlement involving an orthodontist.

Indexing terms: Civil liability. Forensic dentistry. Orthodontics. Radiology.

\section{RESUMO}

O artigo tem como objetivo demonstrar a importância de uma documentação radiológica cuidadosa no atendimento odontológico em casos que exista a necessidade de prova pericial em processo de responsabilidade civil envolvendo cirurgião-dentista e paciente. Visa demonstrar a relação entre a confecção da documentação indicada e o bom desenvolvimento do tratamento. Através de relato de caso de acordão envolvendo ortodontista visa-se demonstrar as implicações do não cumprimento do dever ético e legal.

Termos de indexação: Responsabilidade civil. Odontologia legal. Ortodontia. Radiologia.

\section{INTRODUCTION}

Brazilian Civil Law, as of January 10, 2002, in articles 186 and 187, sets forth that "those who, by action or voluntary omission, negligence, or imprudence, violate one's rights and cause harm to another, commit a unlawful act" and that "those who, by unlawful act, cause harm to another, are obliged to make amends'."

Thus, civil liability as defined as the obligation of an individual, through a pecuniary indemnification, to make amends for his/her acts, and the consequences resulting thereof, in an attempt to rectify the harm caused to a third party. The harmed party must, as quickly as possible, have the means through which to return to the state in which the illicit act occurred. This indemnification must take into account the harm suffered, that is, the expenses incurred, such as the need to buy medicines, or the earnings that were lost, such as the time in which the patient was unable to work and the value that was lost because of this. What must also be taken into consideration is the physical and/ or moral damage incurred. The earnings, as regards moral damages, is intended to provide a monetary satisfaction that can, in some way, minimize the plaintiff's suffering ${ }^{2}$. In this case, the value or quantum should be stipulated by the judge upon becoming aware of the extent of this suffering $^{3}$. This awareness is formulated by means of a case study and its circumstances, as well as the subsequent forensics report ${ }^{4}$.

However, to ensure the liability of the independent professional, including the dentist in this case, and the future amends, according to the Consumer Defense Code (Law 8078 from November 11, 1990), guilt must be proven ${ }^{5}$. The professional has the obligation of not causing harm to his/her patient and will be considered at fault if the acts are performed imprudently, when performed in a premeditated manner, when there is technical inaptitude or negligence, and/or when the harm incurred results from the mere lack of attention or carelessness ${ }^{6}$.

It is also essential to determine the causal link between the performed act and the harm incurred by the plaintiff ${ }^{7}$. As this causal link is the connection between the act (action or omission) and the result, damages in this case. Hence, if this damage has not been caused by the

Pontifícia Universidade Católica de Minas Gerais, Programa de Pós-Graduação em Odontologia. Av. Dom José Gaspar, 500, Coração Eucarístico, 30535-901, Belo Horizonte, MG, Brasil. Correspondência para / Correspondence to: BTB NIQUINI. E-mail: <barbaraniquini@hotmail.com >. 
defendant's act, then he/she has no legal liability8.

In today's society, medical and dental errors are perceived more attentively by the harmed individuals, and the Justice system has become more aware of these cases in order to support the individuals who have been the targets of imprudence on the part of some professionals ${ }^{6}$. Being fully aware that injured individuals have the right to seek indemnification for damages caused to them, dentists also face an increasing need to understand their rights and duties. Dentists must always practice their profession in the most technical manner possible and always base their acts on scientific evidence. Yet they must never forget that, in a lawsuit, the fundamental piece of evidence will be the patient's dental record?'

Therefore, the present study seeks to expose important points from a civil liability lawsuit involving a dentist in order to demonstrate some possible errors that these professionals can commit upon underestimating the value of the documentation and the proper safeguarding of dental imagery files.

\section{CASE REPORT}

This case treats a settlement reached regarding a lawsuit for the indemnification of moral damages, filed by the patient after having received dental treatment. The dentist was found guilty regarding the dental treatment provided to the plaintiff.

The judgment was grounded on many points revealed in the lawsuit. To understand this judgment, some of these parts are transcribed below:

"I hereby find that the main appellant has no grounds for his arguments, as he did not fully comply with the need to produce a treatment plan for the plaintiff and much less inform her as regards the treatment stages and the procedures to be adopted, nor did he document the treatment, as would be expected of a responsible professional, even if only to protect himself against future complaints. One need only check the forensic report, included in the proceedings, to infer that the appellant did not act with caution and prudence upon failing to document the pre- and post-treatment stages, which also hindered the collection of forensic evidence, a fact that was reported by the forensic expert. This onus was in fact yours [the dentist's], under penalty of answering for the harm incurred."

This fact was due, according to the expert, to the non-presentation of models, photos, or panoramic teleradiographs by the dentist, the defendant in this lawsuit, even after having been requested by the responsible forensic expert as forensic evidence. This documentation would have allowed for the study of the patient's diagnosis at the beginning of the treatment. The forensic expert and the reviewers were therefore led to believe that, since the defendant did not have the prudence to document the diverse facts of dental treatment, the procedure adopted by the professional was what in fact caused the injury. Professionals who do not properly draft a treatment plan or who do not clarify the treatment stages to the patient will be considered to have acted negligently. The conduct was considered negligent and imprudent, giving grounds to the plaintiff's request for moral damages.

The report also stated: "The proof found in the proceedings allows one to draw the conclusion that the defendant acted imprudently, negligently, and with mal-practice, causing moral damages to the plaintiff, be it because of a lack of clarification to plaintiff concerning the details of the treatment, be it because [the professional] did not document them."

Thus, the settlement, after having reached an agreement between the forensic expert and the reviewers, resulted in the dismissal of any appeal. Moreover, after the defendant had been found guilty, he was found liable for the payment of the sum of $R \$ 15,000.00$ (fifteen thousand reals) in moral damages to the plaintiff.

\section{DISCUSSION}

The relationship between the dentist and the patient constitutes a consumer relationship, as already mentioned above, and is sustained by the Consumer Defense Code. In this respect, the professional will only be held liable if his/ her guilt can be proven, it being the responsibility of the plaintiff to prove this accusation. However, when a patient alleges mal-practice, the responsibility to provide proof may depend on the judge, rendering this action optional, that is, the judge can decide if it will be the defendant's or the plaintiff's responsibility to provide due proof of guilt. The experience of the magistrate will prevail, through his/her review of the case itself, in establishing if there is in fact a lack of sufficient disclosure. This lack of sufficient disclosure occurs not only in socioeconomic parameters, but also in the patient's understanding or not of the technical terms in dentistry. According to the Consumer Defense Code, in article 6, the basic rights of the consumer include: "the facilitation of the defense of one's right, including the 
inversion of the burden of proof, to one's favor, in the civil lawsuit, when, at the judge's discretion, it is similar to the allegation or when it presents a lack of sufficient disclosure, according to ordinary rules of experience." When there is an inversion of the burden of proof, it is the dental professional's responsibility to present evidence to lead the magistrate to conclude that he/she did not act with imprudence, negligence, or mal-practice ${ }^{5}$.

In civil lawsuits, dental records, which contain the imaging files, are the main piece of evidence of the treatment developed by the dental professional. This documentation, when done in a proper manner, must present sufficient evidence to clarify all questions that may need to be answered. In addition to liability cases, this documentation may be necessary in penal cases involving human identification, in estimating the age of individuals, as well as in epidemiological studies and scientific research.

As they are one of the more commonly required pieces of documentation in both civil and penal lawsuits, radiographs should, whenever possible, be duplicated, and they must, in all cases, be correctly identified with the full name of the patient and duly dated ${ }^{9}$. This drafting and safeguarding of these records must be done carefully, in such a way that the material does not deteriorate over time $^{10}$. Dental documentation is the property of the patient and must be delivered to the patient when requested or five years after the end of treatment, as an alternative to the perpetual archiving of the dental documentation. The delivery of all material from the treatment must be given to the patient, together with a receipt signed by the patient or by his/her legal proxy ${ }^{11}$.

Nevertheless, many dental professionals still believe that dental documentation is merely an unnecessary bureaucratic activity, demonstrating their lack of information regarding the legal and ethical implications of their profession. Other reasons alleged include the lack of time and space in the dentist's office. This neglect for exams also demonstrates a flaw in patient care. The awareness of one's responsibility with regard to one's patients should encourage these professionals to be more prudent with documentation and, consequently, with treatments ${ }^{9}$.

In the civil lawsuit related to the settlement presented in this article, the orthodontist failed to

\section{REFERENCES}

1. Brasil. Código Civil, Lei n. 10.406, de 10 de janeiro de 2002. São Paulo: Revista dos Tribunais; 2002. present any of the patient's orthodontic documentation. This specific documentation must consist of intra- and extra-oral photos, panoramic radiographs, and lateral teleradiographs, periapical radiographs of all of the teeth, and study models ${ }^{11}$.

This well-executed and correctly filed radiological documentation, in cases such as this in which the orthodontist is summoned by the court, is of utmost importance in establishing, or not, a causal link ${ }^{12}$.

The magistrate in this case also determined the inversion of the burden of proof. The professional was therefore forced to present documentation that proved his own lack of proof or proof that the documents had been delivered to the patient. In the aforementioned settlement, it is clear that the defendant did not present the requested radiological documentation. Given the understanding that not requesting the dental radiographs in cases in which these are recommended or are essential to the diagnosis or treatment constitutes negligence ${ }^{13}$; that in the field of orthodontics the complexity of the treatments implies the need to produce a large number of documents, which become essential both in the planning and execution of the treatment; and that, in Brazil, the dental professional has the ethical obligation to safeguard this documentation ${ }^{14}$, the court ruled that this professional acted in a negligent manner and that a causal link had been established between the treatment practiced by the dentist and the injury caused to the patient.

\section{CONCLUSION}

Initial radiographic documentation, in addition to aiding in the diagnosis and in the treatment plan, is of utmost importance and can aid the professional in civil lawsuits. In cases in which there is a scientifically proven need for the use of radiographs for the proper execution of the treatment, the failure to present these images can be conclusive in finding the dentist guilty.

\section{Collaborators}

BTB NIQUINI e FCH BOUCHARDET participated in the bibliographical research and writing.FR MANZI guided in Dentistry, radiology and legal methodology.

2. Figueira Junior E, Trindade GO. Responsabilidade do Cirurgião Dentista Frente ao Código de Defesa do Consumidor. Cadernos UniFOA. 2010;5(12):63-70. 
3. Rosa FM, Fernandes MM, Daruge Júnior E, Paranhos LR. Danos materiais e morais em processos envolvendo cirurgiões dentistas no estado de São Paulo. RFO UPF. 2012;17(1):26-30.

4. Fernandes MM, Baldasso RP, Sakaguti N, Bouchardet FCH, Plana JAC, Oliveira RN. Como justificar a ausência do dano estético? Relato de perícia civil odontológica. RBOL. 2017;4(1) (no prelo).

5. Presidência da República, Casa Civil, Subchefia para Assuntos Jurídicos. Código de Defesa do Consumidor. Lei n. 8.078 de 11 de setembro de 1990. Dispõe sobre a proteção do consumidor e dá outras providências. Brasília, Diário Oficial da União, 11 de setembro de 1990;1990 [citado 2016 Mar 10]. Disponível em: < http://www.planalto.gov.br/ccivil_03/leis/L8078.htm>.

6. Minervinol B, Souza OT. Responsabilidade civil e ética do ortodontista. Rev Dental Press Ortodon Ortop Facial. 2004;9(6):90-6. doi: 10.1590/S1415-54192004000600013

7. Silva RHA, Musse JO, Melani RFH. Responsabilidade civil do cirurgião-dentista: a importância do assistente técnico. Rev Dental Press Ortodon Ortop Facial. 2009;14(6):65-71. doi: 10.1590/S1415-54192009000600009

8. Bouchardet FCH, Barroso CLG, Silva RF SILVA. O estabelecimento de nexo causal por meio de perícia odontológica trabalhista implica em indenização ao trabalhador? Relato de caso pericial. RBOL. 2016;3(2):100-9.

9. Costa SM, Braga SL, Abreu MHNG, Bonan PRF. Avaliação da Comprovação de Documentos Emitidos Durante o Atendimento Odontológico e do Arquivamento das Radiografias nos Prontuários de Saúde da Unimontes, Montes Claros, Brasil. Pesq Bras Odontoped Clin Integr. 2008;8(2):209-13.
10. Latorraca MM, Flores MRP, Silva RHA. Conhecimento dos aspectos legais da documentação odontológica de cirurgiõesdentistas do município de Franca, SP, Brasil. RFO. 2012;17(3):26872.

11. Paranhos LR, Salazar M, Torres FC, Pereira AC, Silva RF, Ramos AL. Avaliação do perfil dos profissionais da área de Ortodontia quanto às condutas legais. Dental Press J Orthod. 2011;16(5):127-34. doi: 10.1590/S2176-94512011000500019

12. Vitral RWF, Campos MJS, Guedes CRS. O que há de novo na Odontologia - Documentação ortodôntica: novos aspectos de uma antiga preocupação. Dental Press J Orthod. 2011;16(4):158. doi: 10.1590/S2176-94512011000400002

13. Cruz FMR, Silva M, Chilvarquer I. Responsabilidade civil em radiografia odontológica. Rev ABRO. 2009;10(1):14-9.

14. Silva RF, Chaves $P$, Paranhos LR, Lenza MA, Daruge Júnior E. Utilização de documentação ortodôntica na identificação humana. Dental Press J Orthod. 2011;16(2):52-7. doi: 10.1590/ S2176-94512011000200007

Received on: 15/8/2016

Final version resubmitted on: 31/10/2016

Approved on: 9/12/2016 